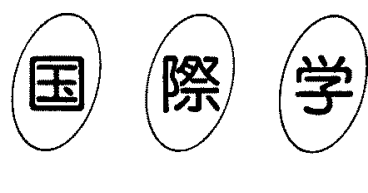

第 8 回国際消化管ホルモンシンポジウム

第 8 回国際消化管ホルモンシンポジウムは9月4日か 58日票で，西ドイののィメンドルファーシュトラ ンドで開催された。ティメンドルファーシニトランド はドイッ北部リニーベック市に近く、バルト游治岸に市 り対岸はすぐデンーークである，地図にも西变り載って いない小さな町ではあるが，夏のあいだは避暑地として 賬わららしい.

9 月初旬とはいえ最高気温は 15 度程度で、戸外はコ ートなしでは路けない泀どすずしかった，大会の受付で シンポジウムの要旨のはいった鞄をもらったが，中に折 り畳及の傘がっていたのには警いた：しかし，会議中 ほとんど毎日のよらに通り雨に出会い納得させられた。

国際消化管ホルモンシンポジウムは2年ごとに開摧さ れるが，それでもこの分野の進展の速さにはなかなか追 いつかない感がある.今回もいくつかの新しいホルキン が明らかにされた.シンポジウムは参加者約 500 人の比 較的小さな規模のもので，臨床に携わ万医者之基礎の研 究者とがほぼ同数を占めているようであった，参加者の なかにはーベル賞受賞者のV.Mutt（スウェーデン） らこの分野のトップレベルの研究者が数多く混じってお り討論の質は非常に高いものか゚あった。参加者のなかで も本ンンポジゥムで得られる情報の多さに渾足している 人が多かった。講演は基調講演数題のほかにポスタ一発 表 283 題と口演 78 題が4.日間にわたって行われた、ポ スタ一発表の後には会議室でテーマごとに拉の沶の2, 3 分すつスライドを使って研究の要約を行った後, 活発 な討諭が行われた. 口演に比べて進行もインフォーマル であったが，そのぶんまったく遠滤のない議論が行われ た. 3 分間の要約に対して討論が 20 分を越壳るものも あった．著者は口演とボスター発表の両方を行ったが， ポスター発表のちとの討論をいれると口演を2回もした ような気分で，瘏労と満足感はこれまでのどの学会上り 姃でった。

シンポジウムは開会式の後, カナダの D. Steiner の 基調講演からスタートした. 膵臓の生成するフミンンと

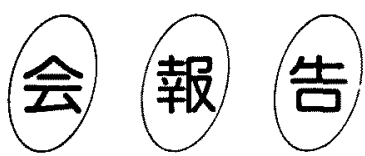

いら新しいペブチドの生合成とプロセッシングに関する 講演が行われたなミリンは膵葴インスリンと同時に分 泌されるペプチドで，糖症病発症との関連が注目されて いる.

続いて, molecular biology のせッションではガスト リン, ソマトスタチン, 世夕レチン, ガラニン, GLP-1, PYY，GIPなどのホルモンの遗伝子発現調節に関する いくつかの研究が発表された。医学・生理学分野の研究 者と生化学分野の研究者との間の其同実験が堌加してい ることが目についた。

一方 new peptide $の$ n⿺ションでは, タキキニン,小 腸 $\mathrm{CCK}$ 分泌べブチド，ェキセンディン， $\mathrm{PACAP，ゼ，}$ ブシンキモデニンなど近年発見あるいは棈造が決定さ れた生理活性ペプチドの報告が注目を集めていた、アミ ノ酸の配列解析技術が近年著しく発達したのは周知のと おらりでこれまで生理活性だけが模出されていて実体が 明かでなかったホルモン様物質の構造決定や遗伝子解析 が猛烈な勢いで進められている。

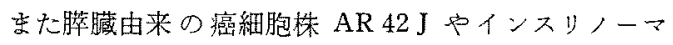
細胞株 RINm 5 F を用いて各種ホルモン受容体, 二次丈 ッセンジャーについての多くの発維が市った。

筆者はとくに小腸から膵臓への信号后達に関寸るセッ ンョンを中心に発表, 討論を行ったが, 本会議において

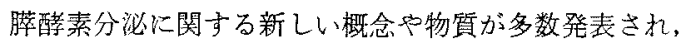
本会議のなかでももっとも活発なヒッションの1つとな った，食物摂取に対する脺応答機構に関する物質とし て，筆者らの見いたしたプロテテーゼ感受性 CCK 分泌 ペプチド（モニターペプチド）の外に，米国 Rochester 大のCheyによって新たにプロテアーゼ感受性のセクレ チン分泌ぺブチドの存在が小腸で報告された。七タレチ ンは膵液だけでなく膵䤕菜の分泌も促進することが最近 定説になりつつあることもありこのペプチドとモ二タ ーペプチドとの類似性が話題になり，筆者も多くの人か ら意見を求められた. Michigan 大の Owyang らはこ れまでに多くの新ホルモンを発見している Stanford 大 の Tatemoto と組んで大量のブタの小腸からとうとう $\mathrm{CCK}$ 分泌ぺプチドを 2 種類临離した. とらと5といら のは前回のンンポジムで艺の精製が報告されていたか 
らである. 1 つはアミ酸 39 個のベプチドで途中をで フミノ酸配列が明らかにされたが，消化管ホルモンの1 種 PYY と類似している.もら一つはつミ/酸 30 個の ベプチドであるが，フミノ末端がブロックされていると いうことで配列決定はまだであった，他にも CCK 分泌 ベプチドの単離構造解析を進めているグループがらわさ されて和り水面下ではかなり醅争は激しそうである。 たさらに膵醉素分泌のフィードバック調節を説明できる ベプチドとして，愺蔵から分泌されるコリパーゼの活性 化フラダメント（䣼素がェンテロキナーゼなどで活性化 されるときに切り出されるぺプチド)に CCK 分泌抑制 活性があり，プロテアーゼでュリパーゼが活性化される 時（小晹内プロテアービレベルが高い時）にこのペプチ ドが CCK 分泌を抑制するという新しい機構がスウニー デンのグループによって発表された。このベプチドは Val-Pro-Asp-Pro-Arg のペンタペブチドであり，彼ら はエンテロスタチンと呼んでいた．活性の発現に Arg 残基が必須であるという。一方，フランスのCubar ら

\section{8th International Symposium on GASTROINTESTINAL HORMONES}

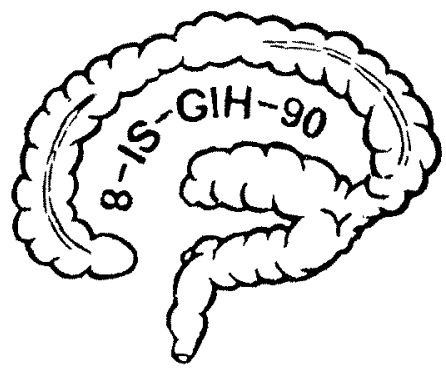

TIMMENDORFER STRAND / Baltic Sea Federal Republic of Germany September $4-8,1990$
のグループは摘出萃臓の邉流実験によってタンパク質の 部分分解ベプチドに CCK 分泌活性がありトリプシンが これを阻害するといら新たなフィードバック機構の可能 性を示唆した：彼らの実験系では，インタクトなタンパ ク質やトリブシンインヒビターはすべて CCK 分泌を促 さずモニターペプチドは一過性の CCK 分泌を示した という．彼らの実験結果はこれまでのインビボの実験と 食い違う点が多く，その食い違いが何に由来するのか今 後解明される必要があるう。モニターペプチドを含め て， CCK 分泌調節に関していくつがのペプチドの棈造 が明らかになりかけてきたかけで、よらやくそれらの生 理的な重要性，生理的な寄与の大きさを論議できる環境 が整った感がある．2年後の1992 年ベルギーでの次回 のシンポジウムではこの点が盛んに議論されるはずであ る.

近年，外分泌が内分泌に与支る影響に対する興味が高 まってきて拈り，本シンポジウムでもそのような発表が 目についた、インスリンなど内分泌と脺外分泌は今日て はかなり遠い分野のような感があり，前者は主に内科， 後者は主に外科の研究者が主に與味を持っているようで ある。しかし，膵ランゲルハンス島（内分泌細胞）は膵 臓では腺房細胞（外分泌細胞）間に点在して括り，両細 胞の増殖，機能発現に相互作用がないはずと考学る研究 者は多くなってきている。

また消化管ホルモンか膵内分泌に与无る影響について も研究加すすんでさている。たとえば CCK がインスり ンを分泌することは生理的意義は別としてよく知られて いる事実である，前出のコリパーゼの活性化フラグメン トやスウェーデンのダルーブが䐁腸から精製したペプチ トPEC-60などがそれぞれインスリン分泌に影響を与え ることも話題になっていた。

プロシーディングは Digestion 誌 46 巻, 補 1 (1990 年）にすでに出版されている。

最後になりましたが（財)農芸化学研究奖励会上り渡 航費の援助を賜わり，貴重な体験を得る機会に惠变れま したことを厚く感謝いたします。

(京都大学䎬学部 伏木 亨) 